\title{
Antifungal effect of 4-arylthiosemicarbazides against Candida species. Search for molecular basis of antifungal activity of thiosemicarbazide derivatives
}

\author{
Agata Siwek • Joanna Stefańska • Katarzyna Dzitko • \\ Artur Ruszczak
}

Received: 22 February 2012 / Accepted: 27 March 2012 /Published online: 26 April 2012

(C) The Author(s) 2012. This article is published with open access at Springerlink.com

\begin{abstract}
The in vitro antifungal potency of six series of 4arylthiosemicarbazides was evaluated. Two isoquinoline derivatives with an ortho-methoxy or ortho-methyl group at the phenyl ring were the most potent antifungal agents. Molecular modeling studies and docking of all 4 -arylthiosemicarbazides into the active sites of sterol $14 \alpha$ demethylase (CYP51), topoisomerase II (topo II), L-glutamine: D-fructose-6-phosphate amidotransferase (GlcN-6-P), secreted aspartic proteinase (SAP), $N$-myristoyltransferase (NMT), and UDP-N-acetylmuramoyl-L-alanine:D-glutamate ligase (MurD) indicated the importance of both structural and electronic factors in ligand recognition and thus for the antifungal effectiveness of 4-arylthiosemicarbazides. A possible antifungal target was identified (NMT) and isoquinoline-thiosemicarbazides showed more favorable affinity than the native ligand.
\end{abstract}

Electronic supplementary material The online version of this article (doi:10.1007/s00894-012-1420-5) contains supplementary material, which is available to authorized users.

\footnotetext{
A. Siwek $(\bowtie)$

Department of Organic Chemistry, Faculty of Pharmacy, Medical University,

Chodźki 4a,

20-093 Lublin, Poland

e-mail: agata.siwek@am.lublin.pl

J. Stefańska

Department of Pharmaceutical Microbiology, Medical University, Oczki 3,

02-007 Warszawa, Poland

K. Dzitko · A. Ruszczak

Department of Immunoparasitology, University of Lodz,

Banacha 12/16,

90-237 Łódź, Poland
}

Keywords Thiosemicarbazide derivative $\cdot$ Antifungal activity $\cdot$ Cytotoxicity $\cdot$ Structure-activity relationship · Molecular docking

\section{Introduction}

Invasive fungal infections (IFIs) are life-threatening opportunistic infections that are an increasingly important cause of morbidity and mortality in patients, especially those with compromised immune function and those hospitalized with serious underlying diseases $[1,2]$. The majority of these infections are caused by Candida spp., with over $50 \%$ due to Candida albicans [3-6]. Candida species are the fourth most common pathogens isolated from patients with nosocomial bloodstream infections in the United States and the sixth in Europe [7-9]. These fungi are responsible for various forms of disease, ranging from superficial infections of the mucosal surfaces or skin to systemic infections, which in most cases are life threatening [10]. The incidence of candidemia in the US and Europe varies between 1.9 and 11 per 100,000 inhabitants [11-13]. Mortality in patients with candidemia is high, ranging from $40 \%$ to $60 \%$, with reported attributable mortality of 20-40\% [9]. In general, for treatment of an infection with Candida species, amphotericin B and azole drugs are used, but these agents are not considered to satisfy medical needs because of their toxicity, side effects, drug interactions, limited routes, and the emergence of drug-resistant and drug-low-susceptible strains [14-21]. Among these limitations, the major obstacle in the treatment of $C$. albicans infections is the spread of antifungal drug resistance, mainly in patients chronically subjected to antimycotic therapy, i.e., those treated with broad-spectrum antibiotics, immunosuppressive agents, 
anticancer, and anti-AIDS drugs [22, 23]. Considering all these factors, the identification of new antifungal small molecules is an important goal of current anti-infective research.

Recently, as a part of our efforts to develop new effective antibacterial agents in the class of thiosemicarbazide derivatives, a series of 4-arylthiosemicarbazides was synthesized and their biological potency evaluated [24]. In vitro antibacterial activity assays indicated that compounds with electron-withdrawing substituents in the para position are more effective. Furthermore, it was documented for the first time that thiosemicarbazide derivatives participate in at least two different mechanisms of antibacterial activity. One of these was identified as inhibition of topoisomerase IV, while the nature of the other could not be elucidated from the limited data collected. The binding mode of the synthesized compounds was explored by flexible molecular docking, which indicated the importance of H-bonding and electrostatic interactions between the thiosemicarbazide core and amino acid residues of the ATP binding site. To further explore the diverse biological activity of thiosemicarbazide derivatives, we focused our attention on the antifungal activity and structure-activity relationships (SAR) of the 4arylthiosemicarbazides, those already described [24-27] and nine new derivatives, using yeast Candida as the experimental model. Since selective toxicity is fundamental to the development of anti-infective agents, cytotoxicity studies were also carried out. Although the antifungal potential of thiosemicarbazide derivatives is well-recognized [28-37], thus far no detailed studies have been conducted to determine the mechanism of action and the target proteins for their antifungal activity. As most of the existing fungal drugs are enzyme inhibitors, the second aim of the present studies was to identify the interactions of 4-arylthiosemicarbazides with antifungal drug target enzymes using in silico molecular docking. In these studies, six common and novel enzymes that were considered in antifungal studies reported in literature [38-41], were selected as targets, i.e., sterol $14 \alpha-$ demethylase (CYP51), topoisomerase II (Topo II), L-glutamine: D-fructose-6-phosphate amidotransferase (GlcN-6-P), secreted aspartic proteinase (SAP), $N$-myristoyltransferase (NMT), and UDP-N-acetylmuramoyl- L-alanine: D-glutamate ligase (MurD).

\section{Materials and methods}

Chemicals

All commercial reactants and solvents were purchased from either Sigma-Aldrich (St. Louis, MO) or Lancaster (Windham, NH) with the highest purity and used without further purification. Melting points were determined on a Fischer-
Johns block and are uncorrected. Elemental analyses were determined by a AMZ-CHX elemental analyzer (within \pm $0.4 \%$ of theoretical values). IR spectra were recorded in KBr using a Specord IR-75 spectrophotometer. ${ }^{1} \mathrm{H}$ NMR spectra were recorded on a Bruker Avance $(300 \mathrm{MHz})$. Analytical thin layer chromatography (TLC) was performed on Merck $60 \mathrm{~F}_{254}$ silica gel plates and visualized by UV irradiation $(254 \mathrm{~nm})$.

Procedure for synthesis of 4-arylthiosemicarbazides

A reaction mixture of appropriate heterocarboxylic hydrazide $(0.01 \mathrm{~mol})$ and related isothiocyanate $(0.01 \mathrm{~mol})$ was heated in an oil bath at $80{ }^{\circ} \mathrm{C}$ and the progress of the reaction was monitored by TLC. After $12 \mathrm{~h}$, the reaction was completed and crude reaction mixture was washed with diethyl ether and crystallized from ethanol.

Physicochemical characterization of 1a-1 m, 3d, 3n, 4b, $4 \mathrm{~d}, 4 \mathrm{p}, 4 \mathrm{q}, 5 \mathrm{c}, 5 \mathrm{~h}, 5 \mathrm{i}, 5 \mathrm{~m}, 5 \mathrm{n}$, and $6 \mathrm{~b}$ were presented previously [24-27]. Compounds $2 \mathrm{c}, 2 \mathrm{~h}, 2 \mathrm{~m}, 2 \mathrm{n}$ are commercially available.

Procedure for synthesis of $s$-triazole 6o-t

The thiosemicarbazide derivative $60(0.01 \mathrm{~mol})$ was dissolved in $2 \% \mathrm{NaOH}(10 \mathrm{~mL})$ and refluxed for $2 \mathrm{~h}$. After cooling, the solution was neutralized with $3 \mathrm{M} \mathrm{HCl}$. The solid formed was filtered, dried and crystallized from ethanol.

Yields and spectral characterization of new compounds are provided in Supplementary Material.

Antifungal assay

The primary screen was carried out by the disc-diffusion method using agar medium, according to the Clinical and Laboratory Standards Institute guidelines [42]. For compounds showing an inhibitory effect on the growth of the tested microorganisms - monitored as an appearance of growth inhibition zones (GIZs) - minimal inhibitory concentrations (MICs) were determined using the agar dilution method, according to Clinical and Laboratory Standards Institute guidelines [43]. The detailed procedure was described in a previous paper [31].

Cytotoxicity assay

\section{Cell culture}

Cell line L929 (ATTC ${ }^{\circledR}$ Catalog No. CCL-1, mouse fibroblasts; http://www.atcc.org) were routinely cultured in Iscove's modified Dulbecco medium (IMDM, Cytogen, Princeton, NJ), supplemented with $10 \%(\mathrm{v} / \mathrm{v})$ fetal bovine serum (FBS, Sigma), plus 2 mM L-glutamine (Sigma), 100.0 
$\mathrm{U} / \mathrm{ml}$ penicillin (Sigma), $100.0 \mu \mathrm{g} / \mathrm{ml}$ streptomycin (Sigma), $5 \times 10^{-5} \mathrm{M} 2$-mercaptoethanol (Sigma) and grown at $37^{\circ} \mathrm{C}$ in a $10 \% \mathrm{CO}_{2}$ humidified environment.

Suspensions of the compounds $1 \mathrm{f}, 1 \mathrm{~h}, 1 \mathrm{~m}, 2 \mathrm{~h}, 5 \mathrm{~h}, 6 \mathrm{~b}$ and 60 were freshly prepared before the cells were exposed, and diluted to appropriate concentrations; $1-1,250 \mu \mathrm{g} / \mathrm{mL}$ for $1 \mathrm{f}$, $1 \mathrm{~h}, 1 \mathrm{~m}, 1-500 \mu \mathrm{g} / \mathrm{mL}$ for $2 \mathrm{~h}, 5 \mathrm{~h}, 6 \mathrm{o}$, and $1-300 \mu \mathrm{g} / \mathrm{mL}$ for $6 \mathrm{~b}$ with the culture medium (containing $2.5 \%$ DMSO). Cells treated with $2.5 \%$ DMSO-solvent served as a control in each experiment.

\section{Cell viability assays}

The effects of tested compounds on the viability of mouse fibroblasts L929 cells were evaluated using the MTT [3(4,5-dimethylthiazol-2-yl)-2,5-diphenyltetrazolium bromide] assay. The MTT assay was used according to international standards: ISO 10993-5:2009 (Tests for in vitro cytotoxicity; http://www.iso.org/iso/catalogue_detail.htm? csnumber $=36406$ ). L929 cells were plated into 96-well plates at a density of $1.0 \times 10^{4} / 100 \mu \mathrm{l} /$ well in culture medium and allowed to attach for $24 \mathrm{~h}$ before treatment. Afterwards, culture medium in the plates was replaced by $100 \mu \mathrm{l}$ compounds suspension at concentration of 0 $565 \mu \mathrm{g} / \mathrm{ml}$ and the cells were exposed for $24 \mathrm{~h}$. Then $1 \mathrm{mg} / \mathrm{ml} \mathrm{MTT}(50 \mu \mathrm{l} / \mathrm{well})$ was added to each well and incubated at $37{ }^{\circ} \mathrm{C}, 10 \% \mathrm{CO}_{2}$ for $2 \mathrm{~h}$. Mitochondrial dehydrogenases of viable cells reduce the yellowish watersoluble MTT to water-insoluble formazan crystals, which were solubilized with dimethyl sulfoxide (DMSO). The cell culture medium was aspirated cautiously, after which $150 \mu \mathrm{l}$ DMSO was added to each well and mixed thoroughly. Optical density (OD) was read on the ELISA reader (Multiskan EX, Labsystems; http://www.mtxlsi.com/multiskan_EX.htm) at $550 \mathrm{~nm}$. The results were expressed as percentage viability compared with the treated $2.5 \%$ DMSO controls. All experiments were performed in triplicate.

Computational details

Physicochemical parameters, HOMO/LUMO maps, and conformational searches were calculated using HyperChem8.0.3
[44]. Extensive conformational searches were carried out using the molecular mechanics level with the OPLS [45, 46] force field. The most stable structures obtained were subsequently optimized to the closest local minimum at the semiempirical level using RM1 parametrization [47]. Convergence criteria were set to 0.1 and $0.01 \mathrm{kcal} \mathrm{mol}^{-1} \AA^{-1}$ for OPLS and RM1 calculations, respectively. Electrostatic potentials were calculated for the geometries that resulted from docking using Gaussian 03 [48] and GaussView 5 [49] at the HF/6-31G level $[50,51]$.

Automated docking setup

Flexible ligand-receptor docking was performed using the AutodockVina program [52] using the default settings. Models of the sterol $14 \alpha$-demethylase (CYP51), topoisomerase II (topo II), L-glutamine: D-fructose-6-phosphate amidotransferase (GlcN-6-P), secreted aspartic proteinase (SAP), N-myristoyltransferase (NMT), and UDP-Nacetylmuramoyl- L-alanine: D-glutamate ligase (MurD) binding sites based on the structure deposited in the Protein Data Bank [53] under the PDB ID 2CIB [54], 1Q1D [55], 1XFF [56], 1EAG [57], 1IYL [58], 1UAG [59] were employed. Default docking parameters and flexible space of $24 \times 24 \times 24 \AA^{3}$ were validated by re-docking native ligand that docked exactly in the position present in the crystal structure. Subsequently, all 4-arylthiosemicarbazides were docked using same docking parameters.

\section{Results and discussion}

\section{Chemistry}

Six series (1-6) of 4-arylthiosemicarbazides were prepared in high yields according to a known procedure [24-27, 60-63] in the reaction of related heterocarboxylic acid hydrazide with aryl isothiocyanate (Scheme 1). This one-step reaction produced nine new $(2 \mathrm{i}, 3 \mathrm{~h}, 3 \mathrm{~m}, 3 \mathrm{q}, 4 \mathrm{k}, 6 \mathrm{k}, 6 \mathrm{n}, 6 \mathrm{o}$, $6 \mathrm{p})$ and 30 known thiosemicarbazides derivatives (1a-1m, 2c, 2h, 2m, 2n, 3c, 3d, 3n, 4b, 4d, 4p, 4q, 5c, 5h, 5i, 5m, 5n, $6 b)$.<smiles>[R4]C(=O)NNNC(=O)c1cc([R2])cc(CC)c1</smiles><smiles>[R4]C(=O)N(N)C(=S)Nc1cccc([R])c1</smiles>

Scheme 1 Preparation of targeted 4-arylthiosemicarbazides, series 1-6. Series 1: 1a-m; series 2: 2c, 2h, 2i, 2m, 2n; series 3: 3c, 3d, 3h, 3m, 3n, 3q; series 4: 4b, 4d, 4k, 4p, 4q;series 5: 5c, 5h, 5i, 5m, 5n; series 6: 6b, 6k, 6n, 6o, 6p. For symbols used to identify studied compounds see Table 1 
Table 1 Symbols used to identify studied compounds using substituents at thiosemicarbazide moiety

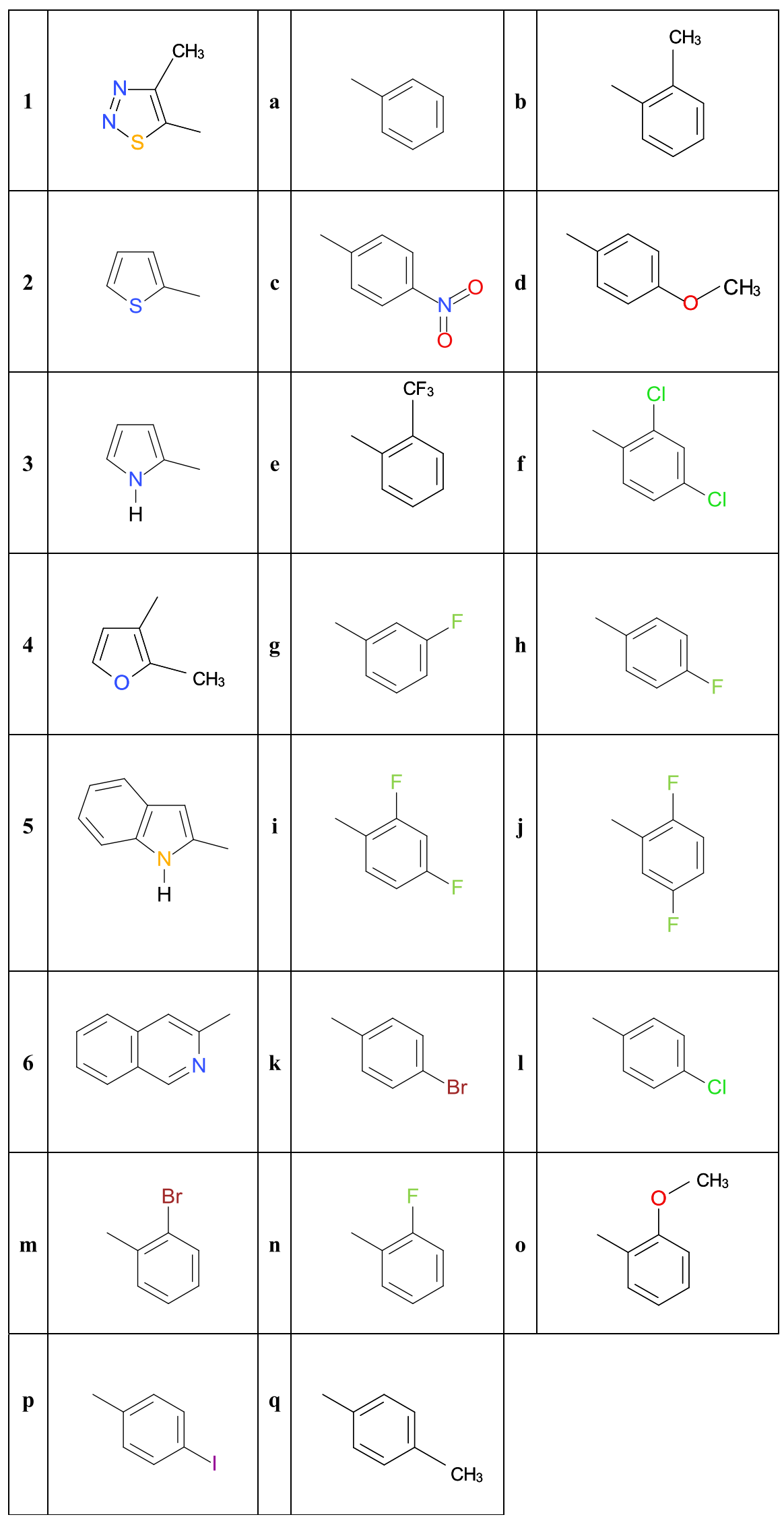


In vitro antifungal activity

The in vitro antifungal activity of the title 4-arylthiosemicarbazides (series 1-6) was tested in comparison with fluconazole against three strains of yeast-C. albicans ATCC 10231, C. albicans ATCC 90028 and C. parapsilosis ATCC 22019-using the agar dilution method as described in CLSI documents M7-A7 [43]. Minimal inhibitory concentrations (MICs) were defined as the lowest concentration of the compound preventing growth of the tested microorganism and are listed in Table 2. The results indicated that within series 1 , compounds $1 \mathrm{c}$ with the para-nitro substitution, and 1f with the ortho and para positions substituted with chlorine atoms were the most potent, exhibiting moderate activity of $50 \mu \mathrm{g} / \mathrm{mL}$ towards $C$. parapsilosis. These compounds were also effective against $C$. albicans, however at much higher concentrations (MIC range 100-200 $\mu \mathrm{g} / \mathrm{mL}$ ). Two other derivatives; $1 \mathrm{~h}$ with para-fluoro substitution and $1 \mathrm{~m}$ with ortho-bromo substitution showed somewhat lower activity, whereas remaining compounds with halo substitution at the ortho and/or para position, 2,4-difluoro derivative $1 \mathrm{i}$, para-bromo derivative $1 \mathrm{k}$, and para-chloro derivative 11 , were inactive. When the thiadiazole scaffold was replaced with the similarly sized thiophene, pyrrole or furane (series 2, 3 and 4, respectively) antifungal potency was lost completely except at $2 \mathrm{~h}$. Subsequently, the antifungal potency of series 5 with an indole scaffold was studied. This search led to the identification of para-fluoro derivative $5 \mathrm{~h}$ and 2,4difluoro derivative $5 \mathrm{i}$ with $\mathrm{MIC}$ at $100 \mu \mathrm{g} / \mathrm{mL}$ towards $C$. parapsilosis and marginal activity towards C. albicans. Remaining derivatives with ortho-fluoro $5 \mathrm{n}$, para-nitro $5 \mathrm{c}$, and ortho-bromo $5 \mathrm{~m}$ substitution were inactive. Replacement of the indole scaffold with the similarly sized isoquinoline resulted in ortho-methoxy derivative 60 with MIC at $25 \mu \mathrm{g} /$ $\mathrm{mL}$ towards $C$. albicans and $50 \mu \mathrm{g} / \mathrm{mL}$ towards $C$. parapsilosis. An antifungal response was also observed for ortho-

Table 2 In vitro antifungal activity [minimal inhibitory concentration (MIC; $\mu \mathrm{g} / \mathrm{mL}$ ) of 4-arylthiosemicarbazides]

\begin{tabular}{llll}
\hline Compound & $\begin{array}{l}\text { Candida albicans } \\
\text { ATCC 10231 }\end{array}$ & $\begin{array}{l}\text { C. albicans } \\
\text { ATCC 90028 }\end{array}$ & $\begin{array}{l}\text { Candida parapsilosis } \\
\text { ATCC 22019 }\end{array}$ \\
\hline $1 \mathrm{c}$ & 100 & 200 & 50 \\
$1 \mathrm{f}$ & 200 & 200 & 50 \\
$1 \mathrm{~h}$ & $>400$ & 400 & 100 \\
$1 \mathrm{~m}$ & 400 & 200 & 100 \\
$2 \mathrm{~h}$ & 400 & 200 & 50 \\
$5 \mathrm{~h}$ & $>400$ & $>400$ & 100 \\
$5 \mathrm{i}$ & $>400$ & 400 & 100 \\
$6 \mathrm{~b}$ & 50 & 50 & 50 \\
$6 \mathrm{o}$ & 25 & 25 & 50 \\
fluconazole & 1 & 1 & 2 \\
\hline
\end{tabular}

methyl derivative $6 \mathrm{~b}$, however, at somewhat higher concentration; MICs at $50 \mu \mathrm{g} / \mathrm{mL}$ towards all screened Candida species. Interestingly, derivatives with electron-withdrawing substitution, para-bromo derivative $6 \mathrm{k}$, ortho-fluoro derivative $6 \mathrm{n}$, and para-iodo derivative $6 \mathrm{p}$ were inactive. Finally, the biological activity of $s$-triazole $60-t$, a cyclic derivative of the most potent 60 , was tested. No antifungal potency was noted.

Cytotoxicity of selected compounds against L929 cells

Compounds 1f, $1 \mathrm{~h}, 1 \mathrm{~m}, 2 \mathrm{~h}, 5 \mathrm{~h}, 6 \mathrm{~b}$, and $6 \mathrm{o}$, all of which showed in vitro antifungal activity, were further examined for their initial in vitro toxicity effects against mammalian L929 cells by MTT assay. Toxicity was defined as the highest dilution of test samples that causes $30 \%$ or greater destruction of cells. Morphology of normal cells and cultured cells with tested compounds are given in Fig. S1 in Supplementary Material.

From a pharmacological point of view it is important for the studied compounds to exhibit high bioactivity and at the same time show no or low toxicity effects, otherwise the activity might just be due to general toxicity, which disqualifies the compound as a drug or lead molecule candidate. From a comparison of the results of toxicity collected in Fig. 1 and antifungal activity tests, it can be seen clearly that the potent anti-Candida agent $6 \mathrm{~b}$ displays antifungal activity at non-cytotoxic concentrations in mammalian cells. Also, compounds $1 \mathrm{f}, 1 \mathrm{~h}$, and $2 \mathrm{~h}$ were found to be non-toxic up to 50 and $100 \mu \mathrm{g} / \mathrm{mL}$, respectively, which equals the MIC values against $C$. parapsilosis. Another important result from the toxicity studies is that the toxicity of the tested compounds does not seem to be correlated to their antifungal activity. For example, 1f, which was found to be nontoxic up to the same concentration as $6 \mathrm{~b}(50 \mu \mathrm{g} / \mathrm{mL})$ is fourtime less active against Candida strains (MIC of 200 vs $50 \mu \mathrm{g} / \mathrm{mL}$ ). Compound $1 \mathrm{~h}$, which was non-toxic up to $100 \mu \mathrm{g} / \mathrm{mL}$, is only marginally active (MIC $400 \mu \mathrm{g} / \mathrm{mL}$ or higher against Candida strains). In contrast, compound 5h,

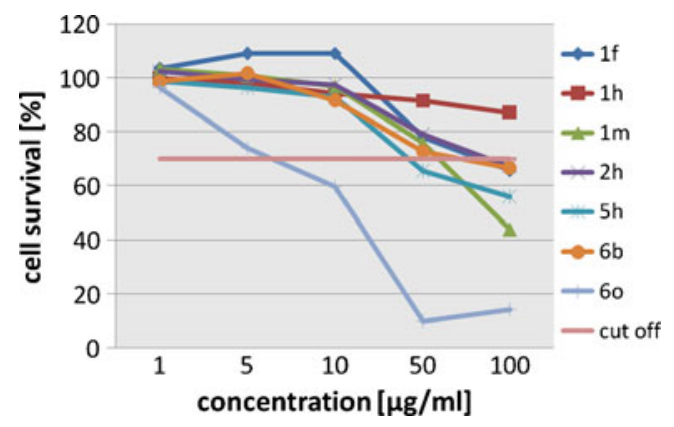

Fig. 1 Concentration-dependent cytotoxic activity of $1 \mathrm{f}, 1 \mathrm{~h}, 1 \mathrm{~m}, 2 \mathrm{~h}$, $5 \mathrm{~h}, 6 \mathrm{~b}$, and $6 \mathrm{o}$ 
which is even less antifungal than $1 \mathrm{~h}$ was found to be nontoxic up to $10 \mu \mathrm{g} / \mathrm{mL}$, while the most cytotoxic $60(5 \mu \mathrm{g} / \mathrm{mL})$ is the most potent antifungal. This indicates either that these compounds may act via different mechanisms in their antifungal activity against $C$. albicans and toxicity against mammalian cells or that minor structural changes afford important alterations in fungal cell permeability/transport, etc. [64]

\section{Molecular modeling studies}

Since the in vitro antifungal activity could not be explained reasonably in the light of theories of the influence of substituents on biological response, the difference in bioactivity of 4-arylthiosemicarbazides was therefore investigated further by a molecular modeling approach and docking studies with the hope of finding a possible explanation for the observations described above, and to provide a better understanding of the relationship between structure and antifungal activity. Initially, some structural and electronic descriptors of the title compounds were investigated (see Table S1 in the Supplementary Material). In the structure of 4-arylthiosemicarbazide, the presence of the isoquinoline ring and electron-donating methyl or methoxy groups (compounds $6 \mathrm{~b}$ and $6 \mathrm{o}$ ) seemed to confer higher antifungal potency than that of other substituted groups. They also are characterized by favorable $E_{\mathrm{B}}$ (binding energy) values and high $\mu$ (dipole moment) and $E_{\mathrm{HOMO}}$ (the highest occupied molecular orbital energy) values in contrast to all other studied compounds. Antifungal activity is probably affected by these electronic descriptors, which can be important parameters for the interaction of 4-arylthiosemicarbazides with the active sites. It is known that the energies of HOMO and lowest unoccupied molecular orbital (LUMO) orbitals serve as indices for the electron-donating and electronacceptor abilities of the molecule, respectively. The higher the energy of the HOMO, the better its electron-donating ability. In the case of LUMO, good electron-acceptor ability is associated with low-energy molecular orbitals. In our results, antifungal potency is related to HOMO, which suggests that electron-donor ability of the molecule is important in determining activity. According to the frontier orbital maps presented in Fig. 2 for representative model compound $6 \mathrm{o}$, the HOMOs of each compound were localized mainly on the sulfur atom of the thiosemicarbazide core. These observations emphasize the possible role of the sulfur atom in the charge transfer processes that occur when a ligand interacts with the biological target.

Subsequently, the localization of LUMO orbitals for each structure was analyzed. There was no quantitative correlation between antifungal activity and LUMO localization, but a trend clearly emerged; 4-arylthiosemicarbazides from series 1, 2, 5, and 6 have their LUMO situated on the heterocyclic ring, whereas LUMO density for compounds from completely inactive series 3 and 4 was distributed outside the heterocyclic moiety, mainly on the sulfur atom. This behavior might be interpreted in the sense that 4arylthiosemicarbazides with the electron-accepting character of the heterocyclic ring at N1 position interact better with the biological target.

Finally, conformational analysis of the studied compounds was performed according to the protocol described for 4-arylthiosemicarbazides with thiadiazole (series 1) and indole (series 5) moieties [24]. As expected based on our previous studies, no structural requirements needed for antifungal activity of 4-arylthiosemicarbazides could be deduced; both isoquinoline derivatives with significant activity, $6 \mathrm{~b}$ and $6 \mathrm{o}$, as well as inactive ones $6 \mathrm{k}, 6 \mathrm{n}$, and $6 \mathrm{p}$ shared very similar geometry. Again, comparison of the molecular shape of active thiophene derivative $2 \mathrm{~h}$ with the most potent antifungal 60 or inactive ones $2 \mathrm{~m}, 2 \mathrm{n}$, $3 \mathrm{~h}, 3 \mathrm{~d}, 4 \mathrm{~b}$ did not show any recognizable relationship with activity (data not shown). Thus, the present study manifested the importance of electronic properties rather than the restricted stereochemistry of the molecule for the antifungal response.
Fig. 2 Highest occupied molecular orbital (HOMO; left) and lowest unoccupied molecular orbital (LUMO; right) contour plots for representative model compound 6o. HOMO and LUMO maps for representative model compounds series 1 and 5 are presented in our previous paper [24]

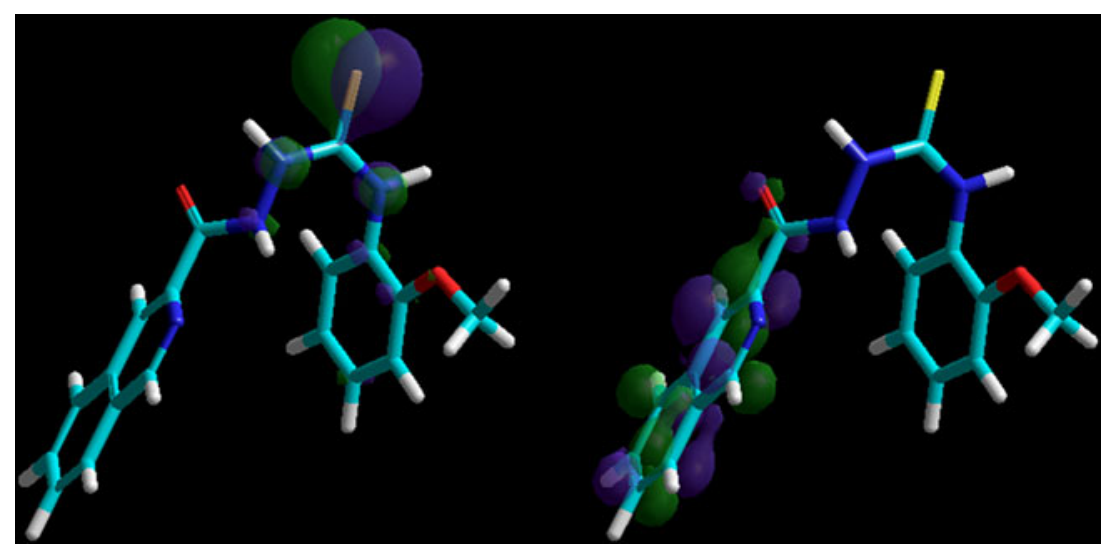




\section{Docking studies}

As noted in the Introduction, with the hope if identifying the fungal cellular targets of thiosemicarbazide class compounds, we analyzed interactions of active and inactive molecules with the active sites of common and novel enzymes that were considered in antifungal studies reported in the literature [38-41]. The following enzymes were included in the studies: sterol $14 \alpha$-demethylase (CYP51), topoisomerase II (Topo II), L-glutamine: D-fructose-6-phosphate amidotransferase (GlcN-6-P), secreted aspartic proteinase (SAP), $N$-myristoyltransferase (NMT), and UDP-Nacetylmuramoyl- L-alanine: D-glutamate ligase (MurD). The docking simulations were performed using the program AutoDock Vina, which was applied successfully in our previous studies of the binding mode of thiosemicarbazide derivatives in the active site of bacterial topoisomerase II [24]. The best poses of the studied compounds within the active sites of target enzymes are displayed in Fig. 3 and their corresponding binding Gibbs free energies $\Delta \mathrm{G}_{\mathrm{b}}$ are shown in Table 3.

As indicated by the positive value of the Gibbs free energy, none of the ligands bound the active sites of
GlcN-6-P and MurD, while potential inhibitory activities of the studied compounds against CYP51, Topo II, SAP, and NMT were observed. Almost all best poses in the series 1-6 were located in a position very similar to that of the inhibitors on which these enzymes were crystallized. Some SAR trends were observed when the docking conformations and binding free energies of the studied compounds in the active site of NMT were analyzed. The nonpeptidic inhibitor that NMT was crystallized with contains a benzofuran core and a long aminoaliphatic chain. From among the compounds studied by us, those containing an isoquinoline ring (series 6) show more favorable binding affinity than the native ligand, and bind to the site occupied by the benzofuran ring. The remaining compounds, series $1-5$, show binding Gibbs free energies lower than the native ligand, and bind to the site occupied by the aminoaliphatic chain situated at position 4 of the benzofuran ring, except for $1 \mathrm{a}, 1 \mathrm{~b}, 2 \mathrm{~h}, 5 \mathrm{c}, 5 \mathrm{~h}, 5 \mathrm{i}$, and $5 \mathrm{~m}$ (Fig. 4). This supports the conclusion reached from experiments [58] that the part of the active site to which the benzofuran moiety is allocated is responsible mainly for binding. Another significant finding is that, with the exception of

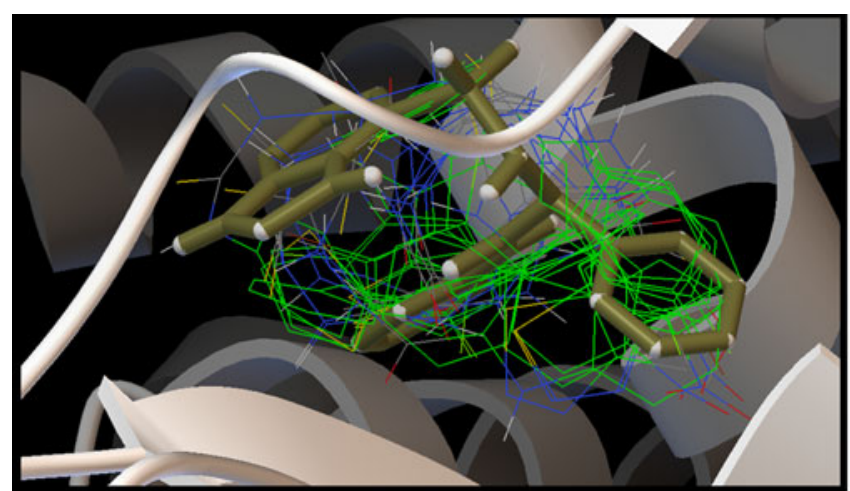

CYP51 (ID 2cib)

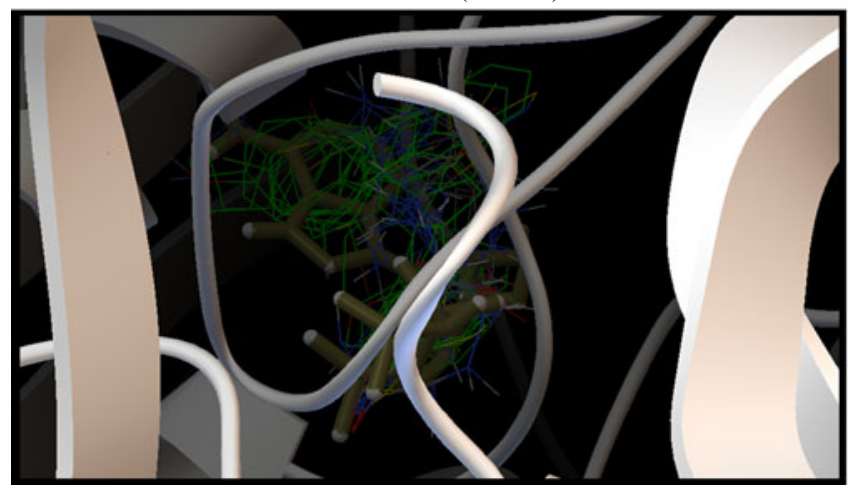

Topo II (ID 1q1d)

Fig. 3 Superimposition of the native ligand (rendered as tubes) and the best conformations of representative ligands $1 \mathrm{a}, 1 \mathrm{~b}, 1 \mathrm{c}, 1 \mathrm{f}, 1 \mathrm{~h}, 1 \mathrm{~m}, 2 \mathrm{c}$, $2 \mathrm{~h}, 3 \mathrm{n}, 3 \mathrm{q}, 4 \mathrm{~d}, 4 \mathrm{k}, 5 \mathrm{c}, 5 \mathrm{~h}, 5 \mathrm{i}, 5 \mathrm{n}, 6 \mathrm{~b}, 6 \mathrm{n}, 6 \mathrm{o}$, and $6 \mathrm{p}$ docked to the
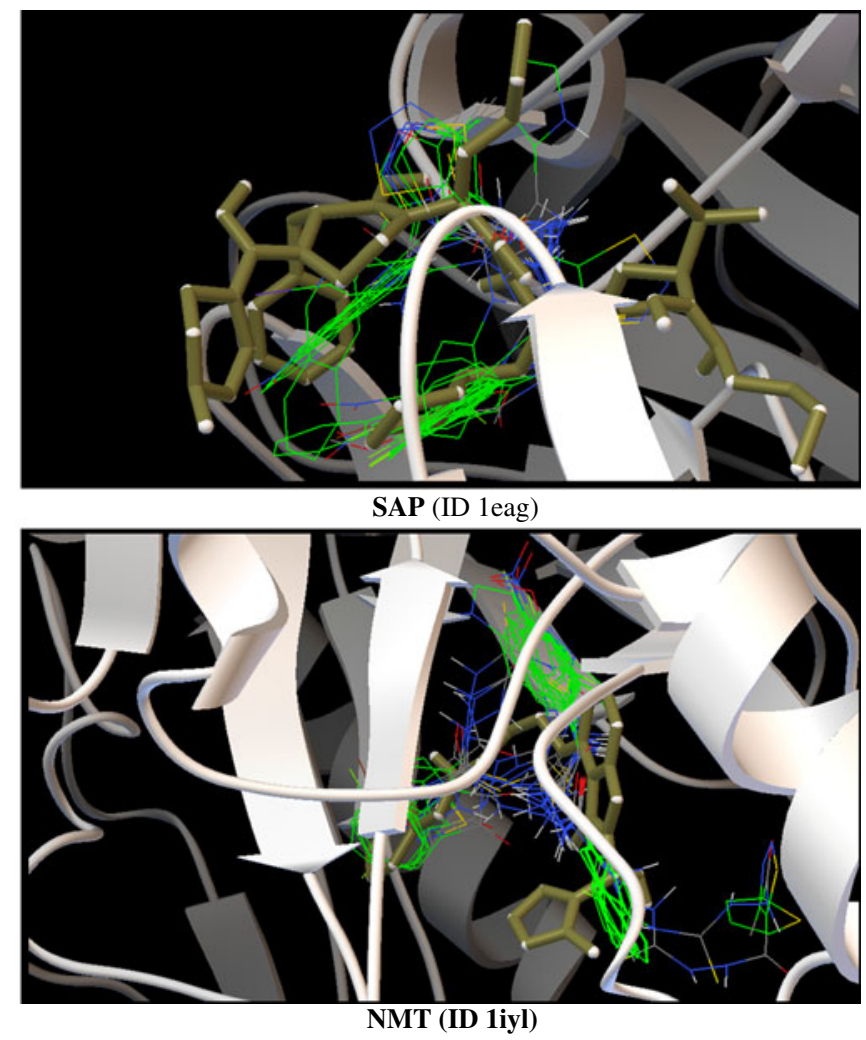

binding site of sterol $14 \alpha$-demethylase (CYP51) (ID 2cib), topoisomerase II (Topo II) (ID 1q1d), secreted aspartic proteinase (SAP) (ID 1eag), and $N$-myristoyltransferase (NMT) (ID 1iyl) 
Table 3 Binding free energy $\left(\Delta \mathrm{G}_{\mathrm{b}}\right)$ corresponding to the best docking poses of compounds from series 1-6 in the active site of CYP51 (ID 2cib), Topo II (ID 1q1d), GlcN-6-P (ID 1xff), SAP (ID 1eag), NMT (ID 1iyl), and MurD (ID1uag)

\begin{tabular}{|c|c|c|c|c|c|c|}
\hline \multirow[t]{2}{*}{ Compound } & \multicolumn{6}{|c|}{$\Delta \mathrm{G}_{\mathrm{b}}(\mathrm{kcal} / \mathrm{mol})$} \\
\hline & CYP51 & Topo II & GlcN-6-P & SAP & NMT & MurD \\
\hline Ligand & -11.5 & -11.8 & -7.9 & -8.0 & -9.1 & -5.1 \\
\hline $1 \mathrm{a}$ & -6.8 & -8.4 & 2.9 & -7.1 & -7.4 & 19.2 \\
\hline $1 b$ & -7.1 & -8.4 & 5.0 & -7.0 & -8.1 & 22.8 \\
\hline $1 \mathrm{c}$ & -7.1 & -8.6 & 4.6 & -7.0 & -7.6 & 22.8 \\
\hline $1 d$ & -7.0 & -8.4 & 5.2 & -7.1 & -7.1 & 20.8 \\
\hline $1 \mathrm{e}$ & -7.5 & -8.9 & 7.3 & -7.4 & -8.4 & 24.8 \\
\hline $1 \mathrm{f}$ & -7.1 & -8.9 & 7.8 & -7.4 & -7.6 & 24.9 \\
\hline $1 \mathrm{~g}$ & -6.9 & -8.6 & 3.3 & -7.2 & -7.6 & 19.9 \\
\hline $1 \mathrm{~h}$ & -7.0 & -8.2 & 3.4 & -7.2 & -7.8 & 19.4 \\
\hline $1 \mathrm{i}$ & -7.3 & -8.9 & 4.9 & -7.7 & -7.8 & 20.8 \\
\hline $1 \mathrm{j}$ & -7.2 & -8.8 & 4.8 & -7.8 & -7.7 & 21.6 \\
\hline $1 \mathrm{k}$ & -7.1 & -8.5 & 7.8 & -6.9 & -7.2 & 21.7 \\
\hline 11 & -7.1 & -8.5 & 5.3 & -7.3 & -7.3 & 21.2 \\
\hline $1 \mathrm{~m}$ & -7.2 & -8.3 & 5.9 & -6.7 & -7.6 & 23.6 \\
\hline $2 \mathrm{c}$ & -7.1 & -8.2 & 7.1 & -6.8 & -7.6 & 20.8 \\
\hline $2 \mathrm{~h}$ & -7.5 & -7.7 & 2.5 & -6.7 & -7.6 & 19.2 \\
\hline $2 \mathrm{i}$ & -7.4 & -7.9 & 2.1 & -7.4 & -7.8 & 19.1 \\
\hline $2 \mathrm{~m}$ & -7.1 & -7.7 & 3.8 & -6.6 & -7.4 & 21.2 \\
\hline $2 n$ & -7.2 & -7.7 & 1.8 & -7.2 & -7.7 & 18.6 \\
\hline $3 c$ & -7.3 & -8.7 & 2.4 & -6.5 & -7.7 & 18.6 \\
\hline $3 d$ & -7.5 & -8.0 & 2.6 & -6.6 & -7.5 & 17.6 \\
\hline $3 \mathrm{~h}$ & -7.7 & -8.1 & 1.7 & -7.3 & -7.6 & 14.8 \\
\hline $3 \mathrm{~m}$ & -7.4 & -7.9 & 2.6 & -6.3 & -7.8 & 18.4 \\
\hline $3 n$ & -7.0 & -8.1 & 0.9 & -7.5 & -7.9 & 15.6 \\
\hline $3 q$ & -7.8 & -8.1 & 1.8 & -6.9 & -7.7 & 16.4 \\
\hline $4 b$ & -7.5 & -8.0 & 4.9 & -7.4 & -8.1 & 20.6 \\
\hline $4 d$ & -7.1 & -7.8 & 5.7 & -7.0 & -7.4 & 21.1 \\
\hline $4 \mathrm{k}$ & -7.3 & -7.8 & 7.0 & -7.0 & -7.4 & 22.1 \\
\hline $4 p$ & -7.2 & -7.9 & 8.0 & -7.0 & -7.4 & 24.5 \\
\hline $4 q$ & -7.5 & -8.0 & 3.6 & -7.3 & -7.5 & 19.5 \\
\hline $5 c$ & -9.7 & -10.0 & 12.2 & -7.2 & -8.2 & 34.1 \\
\hline $5 \mathrm{~h}$ & -9.4 & -8.4 & 10.6 & -7.5 & -8.2 & 28.4 \\
\hline $5 \mathrm{i}$ & -9.6 & -8.7 & 11.6 & -7.8 & -8.7 & 30.9 \\
\hline $5 \mathrm{~m}$ & -9.5 & -9.1 & 10.6 & -8.8 & -8.1 & 32.5 \\
\hline $5 n$ & -9.4 & -8.6 & 8.0 & -7.5 & -7.7 & 29.1 \\
\hline $6 b$ & -7.9 & -8.8 & 11.9 & -7.0 & -10.1 & 33.6 \\
\hline $6 \mathrm{k}$ & -8.2 & -9.1 & 17.2 & -7.0 & -10.1 & 37.9 \\
\hline $6 n$ & -7.9 & -8.9 & 11.7 & -7.4 & -9.8 & 31.2 \\
\hline 60 & -7.7 & -9.0 & 18.5 & -6.9 & -9.5 & 34.6 \\
\hline $6 p$ & -8.2 & -8.9 & 19.3 & -7.0 & -10.0 & 40.6 \\
\hline
\end{tabular}

$2 \mathrm{~h}$ and $2 \mathrm{i}$, all compounds bind to the active site of NMT without H-bond interactions with amino acid residues. This is a very important result, which points to the fact that the electronic nature of a molecule may play the key role in ligand recognition.

Subsequently, we focused on isoquinoline derivatives (series 6) as this series contains the two most active compounds: $6 \mathrm{~b}$ and $6 \mathrm{o}$. Based on the conformations obtained from docking studies, we generated electrostatic potential surfaces. As seen in Fig. 5, the most active compound (6o) is characterized by electrostatics around the sulfur atom that differ significantly from that in the other ligands. The is explained mainly by the opposite orientation of the proton in the neighboring $\mathrm{NH}$ group. Following this finding, we analyzed the geometry of this fragment of the thiosemicarbazide skeleton in detail (Table 4). The opposite location of the $\mathrm{NH}$ proton is characterized by the $\mathrm{HN}(\mathrm{N}) \mathrm{CS}$ dihedral angle being significantly different, and opposite in sign to that in all other compounds. The graphical representation of the different electrostatics in this part of 60 presented in Fig. 5 was quantified by the Mulliken partial atomic charge at the sulfur atom, which was also significantly different and opposite in sign than in other ligands. Two other geometric parameters, i.e., $\mathrm{C}-\mathrm{S}$ bond distance and $\mathrm{HN}(\mathrm{C}) \mathrm{CS}$ dihedral angle, are also distinct in the case of 60 . It should be noted that these differences are very subtle and can be easily overlooked. The importance of electrostatics and geometry of the $-\mathrm{NH}-\mathrm{C}(=\mathrm{S})-\mathrm{NH}-$ fragment can be further inferred from the corresponding parameters of the methyl derivative $6 \mathrm{~b}$. As can be seen in Table $4,6 \mathrm{~b}$ is closer to $6 \mathrm{o}$ than to the remaining ligands. This correlates well with bioactivity, with that of $6 \mathrm{~b}$ being lower than that of 60 and the other ligands being inactive.

Based on the above analysis, we also addressed the question of the lack of antifungal activity of $s$-triazole 6o-t, which is a dehydroderivative of the most active thiosemicarbazide 6o. We docked compound 6o-t to the active site of NMT. As illustrated in Fig. 6, the best pose of 6o-t shows only partial overlap with the corresponding pose of 60 , which coincides well with the position of the ligand used in crystallographic studies. Most importantly, the orientation of the $\mathrm{N}-\mathrm{C}(=\mathrm{S})-\mathrm{N}$ fragment of the $s$-triazole ring is completely different and the location of the sulfur atom within the active site is completely different, $8.7 \AA$ away from the location of sulfur atom of 60 , which, as argued above, influences the antifungal activity of this ligand. Thus, the structural and electronic factors of the $\mathrm{NH}-\mathrm{NH}-\mathrm{C}(=\mathrm{S})-\mathrm{NH}$ core seem to be important for ligand recognition and, consequently, for the antifungal effectiveness of the studied 4arylthiosemicarbazides. Only use of specific enzymatic bioassays, will allow this hypothesis to be confirmed and the biological target of the tiosemicarbazide class of compounds to be identified unequivocally. 
Fig. 4 Superimposition of the native ligand (rendered as tubes) and the best conformations of ligands from series $1-6$ docked to the binding site of NMT (1iyl)

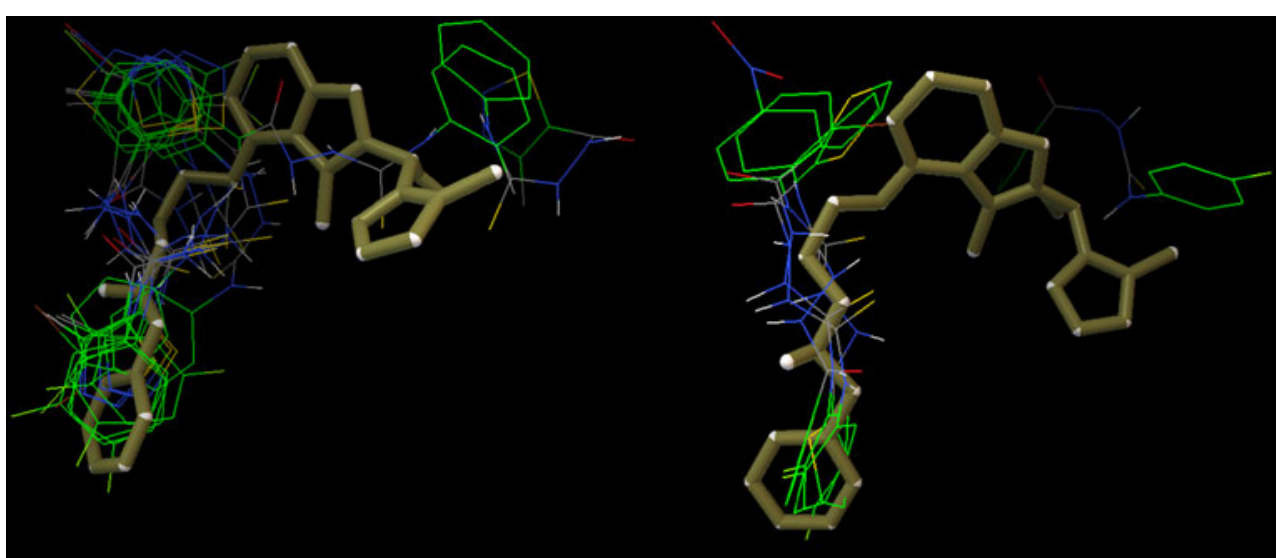

series 1

series 2

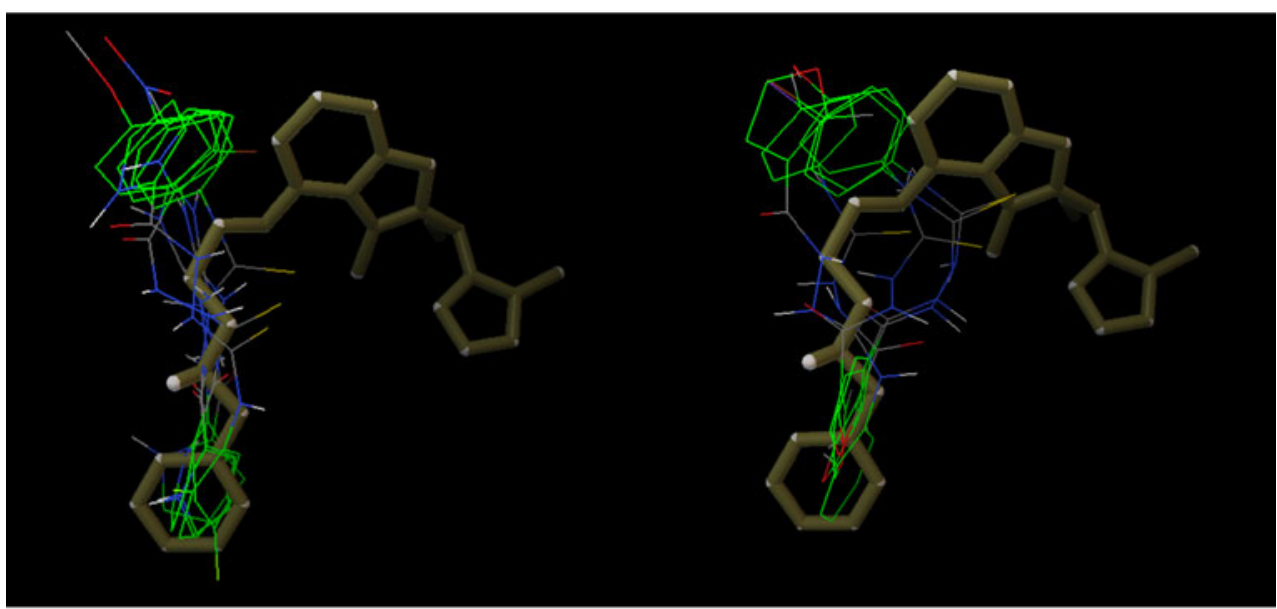

series 3

series 4

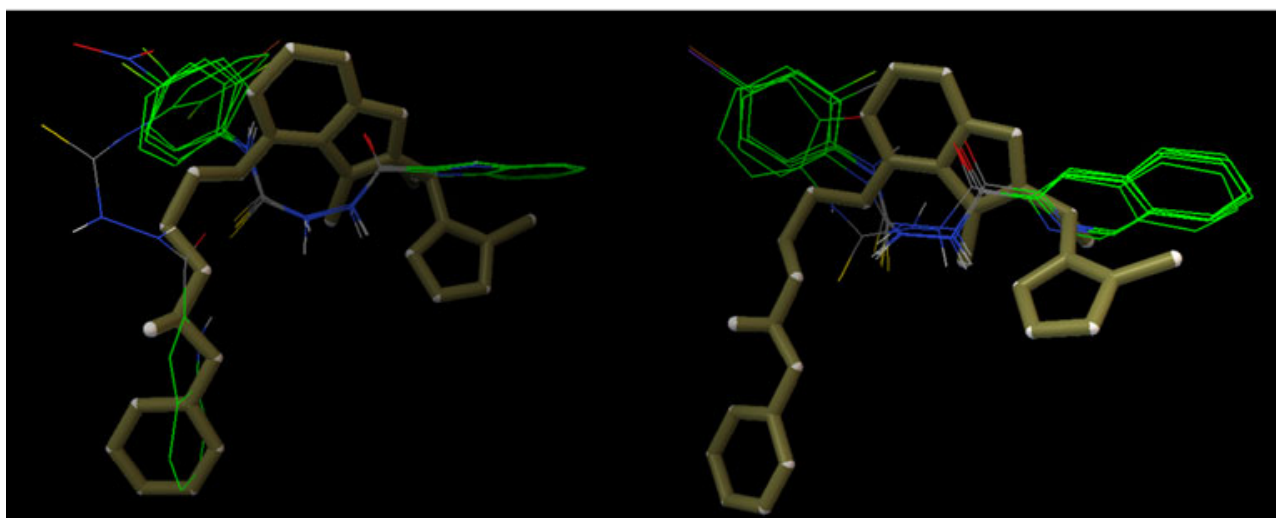

series 5

\section{Conclusions}

The present study evaluated the in vitro antifungal activities of six series of 4-arylthiosemicarbazides. Among the compounds tested, two isoquinoline derivatives 60 and $6 \mathrm{~b}$ were the most potent antifungals. Subsequently, molecular modeling and flexible docking studies were carried out to identify and characterize the structural and electronic properties that modulate the antifungal potency of 4-arylthiosemicarbazides. The electronic requirements for antifungal effectiveness deduced from the molecular modeling approach are (1) high HOMO and dipole moment values, (2) favorable binding energy, and (3) the presence of an electron accepting heteroaromatic ring at N1 position of thiosemicarbazide skeleton. The structural and electronic requirements for ligand recognition deduced from comparisons of ligands in the active site of NMT are (1) high-electron density 


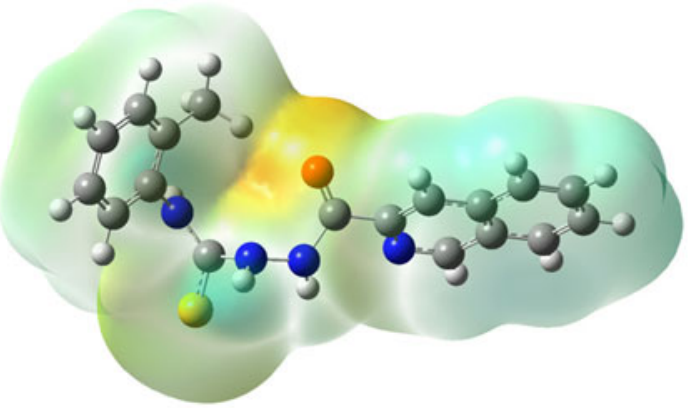

6b

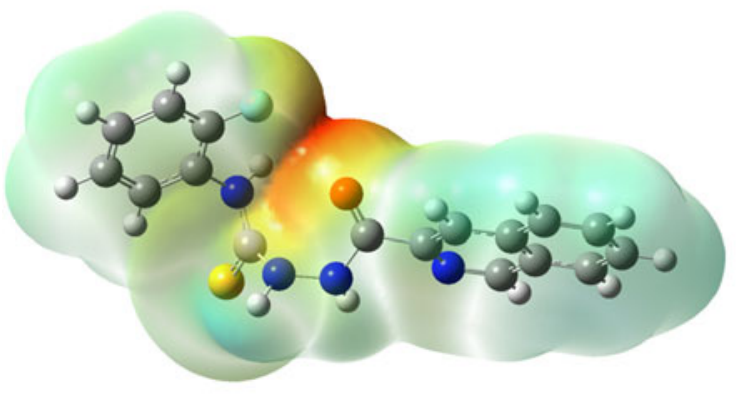

6n

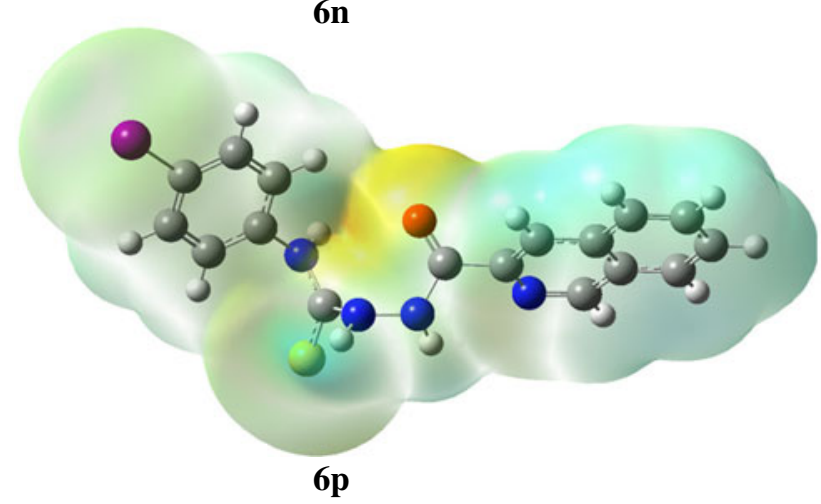

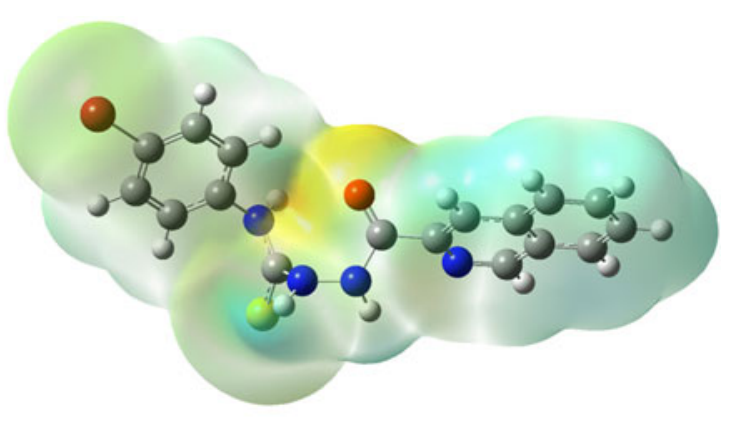

$6 \mathbf{k}$

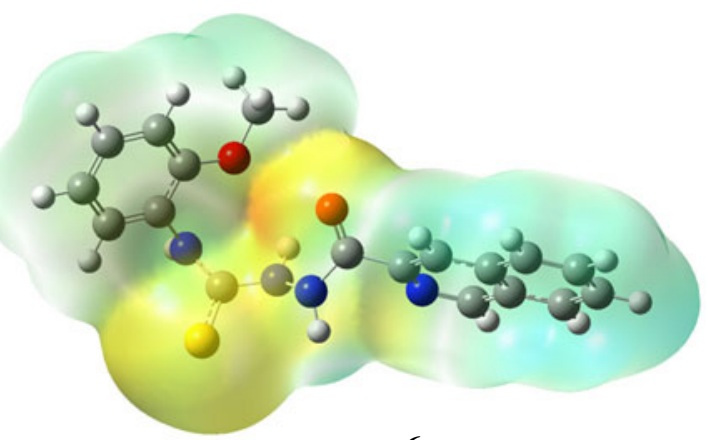

60

Fig. 5 Comparison of the electrostatic potential surfaces of compounds from series 6 that resulted from docking studies at the active site of NMT

around the sulfur atom, and (2) geometry of NH-NH-C(=S)-NH core. The results of the docking study of inactive $s$-triazoles $60-$ t, a dehydroderivative of the most potent antifungal agent 60 , confirmed the validity of the pharmacophore model developed for 4-arylthiosemicarbazides, although additional experimental evidence is needed to support this hypothesis. Efforts aimed at

Table 4 Sulfur charge density $\left(\left|\mathrm{e}^{-}\right|\right)$, selected bond lengths $(\AA)$ and torsional angles $\left(^{\circ}\right)$ of compounds from series 6

\begin{tabular}{lllll}
\hline Compound & S charge density & $\mathrm{C}=\mathrm{S}$ & $\mathrm{HN}(\mathrm{C}) \mathrm{CS}$ & $\mathrm{HN}(\mathrm{N}) \mathrm{CS}$ \\
\hline $6 \mathrm{~b}$ & 0.012 & 1.610 & -58.8 & -71.0 \\
$6 \mathrm{k}$ & 0.064 & 1.608 & -79.6 & -58.9 \\
$6 \mathrm{n}$ & 0.074 & 1.608 & -87.1 & -56.1 \\
$6 \mathrm{o}$ & -0.016 & 1.612 & -99.8 & 171.6 \\
$6 \mathrm{p}$ & 0.070 & 1.609 & -82.1 & -60.9 \\
\hline
\end{tabular}

elucidating the antifungal mechanism of action of 4arylthiosemicarbazides using biochemical approaches are underway in our group.

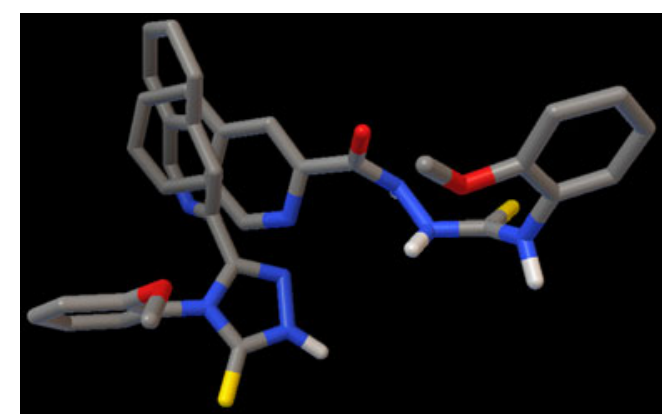

Fig. 6 Superimposition of the best conformations of 60 and $60-t$ docked to the binding site of NMT (1iyl) 
Open Access This article is distributed under the terms of the Creative Commons Attribution License which permits any use, distribution, and reproduction in any medium, provided the original author(s) and the source are credited.

\section{References}

1. Pfaller MA, Diekma DJ (2007) Epidemiology of invasive candidiasis: persistent public health problem. Clin Microbiol Rev 20:133-163

2. Negri M, Martins M, Henriques M, Svidzinski TI, Azeredo J, Oliveira R (2010) Examination of potential virulence factors of Candida tropicalis clinical isolates from hospitalized patients. Mycopathologia 169:175-182

3. Borg-von Zepelin M, Kunz L, Rüchel R, Reichard U, Weig M, Gross U (2007) Epidemiology and antifungal susceptibilities of Candida spp. to six antifungal agents: results from a surveillance study on fungaemia in Germany from July 2004 to August 2005. J Antimicrob Chemother 60:424-428

4. Mercedes Panizo M, Reviakina V, Dolande M, Selgrad S (2008) Candida spp. in vitro susceptibility profile to four antifungal agents. Resistance surveillance study in Venezuelan strains. Med Mycol 24:1-7

5. Richardson M, Lass-Flörl C (2008) Changing epidemiology of systemic fungal infections. Clin Microbiol Infect 14:5-24

6. Pappas PG, Kauffman CA, Andes D, Benjamin DK Jr, Calandra TF, Edwards JE Jr, Filler JF, Kullberg BJ, Ostrosky-Zeichner L, Reboli AC, Rex JH, Walsh TJ, Sobel JD (2009) Clinical practice guidelines for the management of candidiasis: 2009 update by the Infectious Diseases Society of America. Clin Infect Dis 48:503535

7. Pfaller MA, Diekema DJ, Jones RN, Sader HS, Fluit AC, Hollis RJ, Messer SA (2001) International surveillance of bloodstream infections due to Candida species: frequency of occurrence and in vitro susceptibilities to fluconazole, ravuconazole, and voriconazole of isolates collected from 1997 through 1999 in the SENTRY antimicrobial surveillance program. J Clin Microbiol 39:32543259

8. Wisplinghoff H, Bischoff T, Tallent SM, Seifert H, Wenzel RP, Edmond MB (2004) Nosocomial bloodstream infections in US hospitals: analysis of 24,179 cases from a prospective nationwide surveillance study. Clin Infect Dis 39:309-317

9. Méan M, Marchetti O, Calandra T (2008) Bench-to-bedside review: Candida infections in the intensive care unit. Crit Care 12:204-212

10. Lass-Flörl C (2009) The changing face of epidemiology of invasive fungal disease in Europe. Mycoses 52:197-205

11. Diekema DJ, Messer SA, Brueggemann AB, Coffman SL, Doern GV, Herwaldt LA, Pfaller MA (2002) Epidemiology of candidemia: 3-year results from the emerging infections and the epidemiology of Iowa organisms study. J Clin Microbiol 40:1298-1302

12. Kao AS, Brandt ME, Pruitt WR, Conn LA, Perkins BA, Stephens DS, Baughman WS, Reingold AL, Rothrock GA, Pfaller MA, Pinner RW, Hajjeh RA (1999) The epidemiology of candidemia in two United States cities: results of a populationbased active surveillance. Clin Infect Dis 29:1164-1170

13. Tortorano AM, Kibbler C, Peman J, BernhardtH KL, Grillot R (2006) Candidaemia in Europe: epidemiology and resistance. Int J Antimicrob Agents 27:359-366

14. Enoch DA, Ludlam HA, Brown NMJ (2006) Invasive fungal infections: a review of epidemiology and management options. J Med Microbiol 55:809-818
15. Blot S, Vandewoude K (2004) Management of invasive candidiasis in critically ill patients. Drugs 64:2159-2175

16. Hakki M, Staab JF, Marr KF (2006) Emergence of a Candida krusei isolate with reduced susceptibility to caspofungin during therapy. Antimicrob Agents Ch 50:2522-2524

17. Moudgal V, Little T, Boikov D, Vazquez JA (2005) Multiechinocandinand Multiazole-resistant Candida parapsilosis isolates serially obtained during therapy for prosthetic valve endocarditis. Antimicrob Agents Chemother 49:767-769

18. Arendrup MC, Fuursted K, Gahrn-Hansen B, Jensen IM, Knudsen JD, Lundgren B, Schonheyder HC, Tvede MJ (2005) Seminational surveillance of fungemia in Denmark: notably high rates of fungemia and numbers of isolates with reduced azole susceptibility. $\mathrm{J}$ Clin Microbiol 43:4434-4340

19. Hobson RPJ (2003) The global epidemiology of invasive Candida infections - is the tide turning? J Hosp Infect 55:159-168

20. Verweij PE, Snelders E, Kema GHJ, Mellado E, Melchers JGM (2009) Azole resistance in Aspergillus fumigatus: a side-effect of environmental fungicide use? Lancet Infect Dis 6:789-795

21. Groll AH, De Lucca AJ, Walsh TJ (1998) Emerging targets for the development of novel antifungal therapeutics. Trends Microbiol 6:117-124

22. Sheehan DJ, Hitchcock CA, Sibley CM (1999) Current and emerging azole antifungal agents. Clin Microbiol Rev 12:40-79

23. Schiaffella F, Macchiarulo A, Milanese L, Vecchiarelli A, Costantino G, Pietrella D, Fringuelli R (2005) Design, synthesis, and microbiological evaluation of new Candida albicans CYP51 inhibitors. J Med Chem 48:7658-7666

24. Siwek A, Stączek P, Stefańska J (2011) Synthesis and structureactivity relationship studies of 4-arylthiosemicarbazides as topoisomerase IV inhibitors with Gram-positive antibacterial activity. Search for molecular basis of antibacterial activity of thiosemicarbazides. Eur J Med Chem 46:5717-5726

25. Siwek A, Wujec M, Dobosz M, Wawrzycka-Gorczyca I (2010) Study of direction of cyclization of 1-azolil-4-aryl/alkyl-thiosemicarbazides. Heteroatom Chem 21:521-532

26. Siwek A, Wujec M, Stefańska J, Paneth P (2009) Antimicrobial properties of 4-aryl-(2-methyl-furan-3-yl)- $\Delta^{2}-1 \mathrm{H}-1,2,4$-triazolethiones. Phosphorus Sulfur 184:3149-3159

27. Wawrzycka I, Siwek A, Kosikowska U, Malm A (2011) Synthesis and crystal structure of $N$-butyl-5-(4-methyl-1,2,3-thiadiazol-5-yl)1,3,4-thiadiazol-2-amine and 5-isoquinolin-3-yl- $N$-(2-methylphenyl)1,3,4-thiadiazol-2-amine. Z Kristallogr 226:297-302

28. Çapan G, Ulusoy N, Ergenç N, Kiraz M (1999) New 6Phenylimidazo2,1-b]thiazole derivatives: synthesis and antifungal activity. Monatsh Chem 130:1399-1407

29. Dogan HN, Rollas S, Erdeniz H (1998) Synthesis, structure elucidation and antimicrobial activity of some 3-hydroxy-2-naphthoic acid hydrazide derivatives. Farmaco 53:462-467

30. Farag AM, Mayhoub AS, Barakat SE, Bayomi AH (2008) Synthesis of new N-phenylpyrazole derivatives with potent antimicrobial. Bioorg Med Chem 16:4569-4578

31. Siwek A, Stefańska J (2011) Antimicrobial activity and SAR study of some novel thiosemicarbazide derivatives bearing piperidine moiety. Med Chem 7:690-696

32. Salgın-Gökșen U, Gökhan-Kelekçi N, Göktaș Ö, Köysal Y, Kılıç E, Işık S, Aktay G, Özalp M (2007) 1-Acylthiosemicarbazides, 1,2,4-triazole-5(4H)-thiones, 1,3,4-thiadiazoles and hydrazones containing 5-methyl-2-benzoxazolinones: synthesis, analgesicanti-inflammatory and antimicrobial activities. Bioorg Med Chem $15: 5738-5751$

33. Wujec M, Kosikowska U, Paneth P, Malm A (2007) Reaction of hydrazide of (tetrazol-5-yl)acetic acid with isothiocyanates and antimicrobial investigations of newly-obtained compouns. Heterocycles 71:2617-2626 
34. Cunha S, Macedo FC Jr, Costa GAN, Rodrigues MT Jr, Verde RBV, de Souza Neta LC, Vencato I, Lariucci C, Sá FP (2007) Antimicrobial activity and structural study of disubstituted thiourea derivatives. Monatsh Chem 138:511-516

35. Kadi AA (2011) Synthesis and antimicrobial activity of some new quinazolin-4(3H)-one derivatives. J Saudi Chem Soc 15:95-100

36. Al-Saadi MS, Faidallah HM, Rostom SAF (2008) Synthesis and biological evaluation of some 2,4,5-trisubstituted thiazole derivatives as potential antimicrobial and anticancer agents. Arch Pharm 341:424-434

37. Jalilian AR, Sattari S, Bineshmarvasti M, Shafiee A, Daneshtalab M (2000) Synthesis and in vitro antifungal and cytotoxicity evaluation of thiazolo-4H-1,2,4-triazoles and 1,2,3-thiadiazolo-4H1,2,4-triazoles. Arch Pharm 333:347-354

38. Ruge E, Korting HC, Borelli C (2005) Current state of threedimensional characterisation of antifungal targets and its use for molecular modelling in drug design. Int J Antimicrob Ag 26:427441

39. Sheng Ch XuH, Wang W, Cao Y, Dong G, Wang S, Che X, Ji H, Miao Z, Yao J, Zhang W (2010) Design, synthesis and antifungal activity of isosteric analogues of benzoheterocyclic N-myristoyltransferase inhibitors. Eur J Med Chem 45:3531-3540

40. Balladka KS, Bettadapura GK, Chenna GD, Basavapattana RB, Hanumanthappa M (2010) Synthesis, characterization, in vitro and molecular docking studies of new 2,5-dichloro thienyl substituted thiazole derivatives for antimicrobial properties. Eur J Med Chem 45:3490-3496

41. Khan SI, Nimrod AC, Mehrpooya M, Nitiss L, Walker LA, Clark AM (2002) Antifungal activity of eupolauridine and its action on DNA topoisomerases. Antimicrob Agents Ch 46:1785-1792

42. Clinical and Laboratory Standards Institute (2006) Performance standards for antimicrobial disc susceptibility tests; approved standard M2-A9. Clinical and Laboratory Standards Institute, Wayne, PA

43. Clinical and Laboratory Standards Institute (2006) Methods for dilution antimicrobial susceptibility tests for bacteria that grow aerobically; approved standard M7-A7. Clinical and Laboratory Standards Institute, Wayne, PA

44. HyperChem 8.0.3 (2007) HyperCube, Gainsville, FL

45. Jorgensen WL, Maxwell DS, Tirado-Rives J (1996) Development and testing of the OPLS all-atom force field on conformational energetics and properties of organic liquids. J Am Chem Soc 118:11225-11236

46. Jorgensen WL, McDonald NA (1998) Development of an all-atom force field for heterocycles. Properties of liquid pyridine and diazenes. J Mol Struct (THEOCHEM) 424:145-155

47. Rocha GB, Freire RO, Simas AM, Stewart JJP (2006) Rm1: A reparameterization of $\mathrm{AM} 1$ for $\mathrm{H}, \mathrm{C}, \mathrm{N}, \mathrm{O}, \mathrm{P}, \mathrm{S}, \mathrm{F}, \mathrm{Cl}, \mathrm{Br}$, and I. J Comput Chem 27:1101-1111

48. Frisch MJ, Trucks GW, Schlegel HB, Scuseria GE, Robb MA, Cheeseman JR, Montgomery JA Jr, Vreven T, Kudin KN, Burant JC, Millam JM, Iyengar SS, Tomasi J, Barone V, Mennucci B, Cossi M, Scalmani G, Rega N, Petersson GA, Nakatsuji H, Hada M, Ehara M, Toyota K, Fukuda R, Hasegawa J, Ishida M, Nakajima T, Honda Y, Kitao O, Nakai H, Klene M, Li X, Knox JE, Hratchian HP, Cross JB, Bakken V, Adamo C, Jaramillo J, Gomperts R, Stratmann RE, Yazyev O, Austin AJ, Cammi R, Pomelli C, Ochterski JW, Ayala PY, Morokuma K, Voth GA, Salvador P, Dannenberg JJ, Zakrzewski VG, Dapprich S, Daniels AD, Strain MC, Farkas O, Malick DK, Rabuck AD, Raghavachari K, Foresman JB, Ortiz JV, Cui Q, Baboul AG, Clifford S, Cioslowski J, Stefanov BB, Liu G, Liashenko A, Piskorz P, Komaromi I, Martin RL, Fox DJ, Keith T, Al-Laham MA, Peng CY, Nanayakkara A, Challacombe M, Gill PMW, Johnson B, Chen W, Wong MW, Gonzalez C, Pople JA (2004) Gaussian03, Revision D.01. Gaussian, Wallingford, CT
49. Dennington II R, Keith T, Millam J, Eppinnett K, Hovell WL, Gilliland R (2003) GaussView, Version 3.0. Semichem, Shawnee Mission, KS

50. Francl MM, Pietro WJ, Hehre WJ, Binkley JS, Gordon MS, Defrees DJ, Pople JA (1982) Self-consistent molecular orbital methods XXIII. A polarization-type basis set for second-row elements. J Chem Phys 77:3654-3665

51. Hariharan PC, Pople JA (1973) The influence of polarization functions on molecular orbital hydrogenation energies. Theor Chim Acta 28:213-222

52. Trott O, Olson AJ (2010) AutoDockVina: improving the speed and accuracy of docking with a new scoring function, efficient optimization and multithreading. J Comput Chem 31:455-461

53. Berman HM, Westbrook J, Feng Z, Gilliland G, Bhat TN, Weissig H, Shindyalov IN, Bourne PE (2000) The Protein Data Bank. Nucleic Acids Res 28:235-242; http://www.pdb.org

54. Podust LM, von Kries JP, Nasser Eddine A, Kim Y, Yermalitskaya LV, Kuehne R, Ouellet H, Warrier T, Alteköster M, Lee J-S, Rademann J, Oschkinat H, Kaufmann SHE, Waterman MR (2007) Small-molecule scaffolds for CYP51 inhibitors identified by high-throughput screening and defined by X-ray crystallography. Antimicrob Agents Chemother 51:3915-3923

55. Classen S, Olland S, Berger JM (2003) Structure of the topoisomerase II ATPase region and its mechanism of inhibition by the chemotherapeutic agent ICRF-187. Proc Natl Acad Sci USA 100:10629-10634

56. Isupov MN, Obmolova $\mathrm{G}$, Butterworth $\mathrm{S}$, Badet-Denisot MA, Badet B, Polikarpov I, Littlechild JA, Teplyakov A (1996) Substrate binding is required for assembly of the active conformation of the catalytic site in Ntn amidotransferases: evidence from the 1.8 A crystal structure of the glutaminase domain of glucosamine 6-phosphate synthase. Structure 4:801-810

57. Cutfield SM, Dodson EJ, Anderson BF, Moody PC, Marshall CJ, Sullivan PA, Cutfield JF (1995) The crystal structure of a major secreted aspartic proteinase from Candida albicans in complexes with two inhibitors. Structure 3:1261-1271

58. Sogabe S, Masubuchi M, Sakata K, Fukami TA, Morikami K, Shiratori Y, Ebiike H, Kawasaki K, Aoki Y, Shimma N, D'Arcy A, Winkler FK, Banner DW, Ohtsuka T (2002) Crystal structures of Candida albicans N-myristoyltransferase with two distinct inhibitors. Chem Biol 9:1119-1128

59. Bertrand JA, Auger G, Fanchon E, Martin L, Blanot D, van Heijenoort J, Dideberg O (1997) Crystal structure of UDP-Nacetylmuramoyl-L-alanine:D-glutamate ligase from Escherichia coli. EMBO J 16:3416-3425

60. Ezabadi IR, Camoutsis C, Zoumpoulakis P, Geronikaki A, Soković M, Glamoćilija J, Ćirić A (2008) Sulfonamide-1,2,4-triazole derivatives as antifungal and antibacterial agents: Synthesis biological evaluation, lipophilicity, and conformational studies. Bioorg Med Chem 16:1150-1161

61. Kuș C, Ayhan-Kılcıgil G, Özbey S, Kaynak FB, Kaya M, Çoban T, Can-Eke B (2008) Synthesis and antioxidant properties of novel $N$ methyl-1,3,4-thiadiazol-2-amine and 4-methyl-2 $H$-1,2,4-triazole-3 $(4 H)$-thione derivatives of benzimidazole class. Bioorg Med Chem $16: 4294-4303$

62. Önkol T, Doğruer DS, Uzun L, Adak S, Özkan S, Șahin MFJ (2008) Synthesis and antimicrobial activity of new 1,2,4-triazole and 1,3,4-thiadiazole derivatives. Enzyme Inhib Med Chem 23:277-284

63. Shams HZ, Mohareb RM, Helal MH, Mahmoud AE (2007) Synthesis, structure elucidation, and biological evaluation of some fused and/or pendant thiophene, pyrazole, imidazole, thiazole, triazole, triazine, and coumarin systems based on cyanoacetic 2-(benzoylamino)thioxomethyl. hydrazide. Phosphorus Sulfur 182:237-263

64. Babu KS, Li XC, Jacob MR, Zhang Q, Khan SI, Ferreira D, Clark AM (2006) Synthesis, antifungal activity, and structure-activity relationships of coruscanone A analogues. J Med Chem 49:78777886 